\title{
IMPLEMENTASI KEPEMIMPINAN KEPALA SEKOLAH DALAM MEMBINA KOMPETENSI SOSIAL GURU
}

\author{
Bradley Setiyadi ${ }^{1 *}$, Mohamad Muspawi ${ }^{2}$, Ristia Kasiani ${ }^{3}$ \\ ${ }^{123}$ Program Studi Administrasi Pendidikan FKIP Universitas Jambi \\ Email: bradleysetiyadi@unja.ac.id
}

\begin{abstract}
Abstrak
Kepala sekolah sebagai pemimpin harus mampu meningkatkan pemberdayaan dan pembinaan bagi guru- guru melalui peningkatan manajemen sumber daya manusia. Oleh karena itu kepala sekolah mempunyai kewajiban dan tanggung jawab untuk mengembangkan kompetensi guru. Penelitian ini bertujuan untuk mendeskripsikan serta menguraikan faktor pendukung dan penghambat implementasi kepemimpinan kepala sekolah dalam membina kompetensi sosial guru. Penelitian ini dilaksanakan di SMA Negeri 7 Kerinci.menggunakan metode penelitian kualitatif deskriptif dengan jenis penelitian studi kasus. Teknik pengumpulan data dalam penelitian ini menggunakan observasi, wawancara dan studi dokumentasi. Teknik analisis penyajian data dimulai dari pengumpulan seluruh data hasil observasi,wawancara dan studi dokumentasi. Kemudian dilanjutkan dengan reduksi data, penyajian data dan ditarik kesimpulan.Sedangkan uji keabsahan data menggunakan Triangulasi data. Hasil dari penelitian ini menunjukkan bahwa : 1) Pembinaan dalam Komunikasi dan bergaul secara efektif di SMA Negeri 7 Kerinci sudah cukup baik dengan adanya bentuk penerapan Piket Simpatik bagi seluruh elemen sekolah. 2) Pembinaan Manajemen Hubungan Sekolah dan masyarakat serta ikut berperan aktif di masyarakat sudah cukup baik dengan adanya penerapan Pembinaan synergy building bagi guru di SMA Negeri 7 Kerinci. 3) Pembinaan dalam menyiapkan guru sebagai agen perubahan sosial sudah cukup baik dengan adanya bentuk pembinaan MGMP bagi seluruh elemen sekolah di SMA Negeri 7 Kerinci. Sedangkan Faktor Penghambat dalam membina kompetensi guru di SMA Negeri 7 Kerinci adalah kurangnya inisiatif Kepala Sekolah dan kesadaran guru dalam mengadakan pembinaan guna meningkatkan kompetensi sosial bagi guru.
\end{abstract}

Kata Kunci : kepemimpinan kepala sekolah, kompetensi sosial guru

\begin{abstract}
The principal as a leader must be able to increase empowerment and guidance for teachers through improving human resource management. Therefore the principal has the obligation and responsibility to develop teacher competence. This study aims to describe the supporting and inhibiting factors for the implementation of the principal's leadership in building up teacher social competence. This research was conducted at SMA Negeri 7 Kerinci using descriptive qualitative research methods with case study research. Data collection techniques in this study were observation, interviews, and documentation studies. The data presentation analysis technique started from the collection of all data from observations, interviews, and documentation studies. Then it was followed by data reduction, data presentation and conclusions drawn. While the data validity test used data triangulation. The results of this study indicated that: 1) Guidance in communication and socializing effectively in SMA Negeri 7 Kerinci was good enough with the implementation of picket sympathy for all school elements. 2) The development of school and community relationship management and taking an active role in the community was good enough with the implementation of synergy-building guidance for teachers at SMA Negeri 7 Kerinci. 3) Guidance in preparing teachers as agents of social change was good enough with the existence of MGMP guidance for all school elements in SMA Negeri 7 Kerinci. Meanwhile, the inhibiting factor in developing teacher competence in SMA Negeri 7 Kerinci was the lack of initiative of the principal and teacher awareness in providing guidance to improve social competence for teachers.
\end{abstract}

Key Words : principal leadership, teacher social competence 


\section{PENDAHULUAN}

Tugas kepala sekolah sebagai pemimpin adalah harus mampu memberikan petunjuk dan pengawasan, meningkatkan kemauan tenaga kependidikan, membuka komunikasi dua arah dan mendelegasikan tugas.[1].

Salah satu tugas pokok Kepala sekolah yaitu memiliki peranan dan kontribusi yang besar dalam pelaksanaan keberlangsungan kegiatan pendidikan, oleh karena itu kepala sekolah sebagai leader atau pemimpin setidaknya harus mampu meningkatkan pemberdayaan dan pembinaan bagi guru- guru melalui peningkatan manajemen sumber daya manusia, maka kepala sekolah mempunyai kewajiban dan tanggung jawab untuk mengembangkan kompetensi guru. Dengan kata lain, poin yang paling berperan dalam peningkatkan profesionalisme guru di antaranya adalah kepala sekolah. Kepala sekolah mempunyai fungsi yang sangat menentukan bagi perkembangan guru kedepannya. Peran tersebut dapat berdampak positif apabila kepala sekolah mampu meningkatkan potensi guru-guru sekaligus memberikan ruang kebebasan bagi guru dan mendorong guru untuk dapat maju dan berkembang guna meningkatkan kompetensi dan tanggung jawab terhadap tugas dan tanggung jawabnnya sebagai seorang guru. [2]

Standar kompetensi guru adalah suatu gagasan tentang kriteria yang di persyaratkan, di tetapkan, dan di sepakati secara bersama dalam menciptakan penguasaan pengetahuan, keterampilan, dan sikap bagi seorang tenaga kependidikan sehingga layak di sebut kompeten. [3].

Standarisasi kompetensi guru merupakan salah satu tolok ukur yang di tetapkan bagi seorang guru dalam menguasai seperangkat kemampuan agar layak menduduki salah satu jabatan fungsional guru sesuai bidang tugas dan jenjang pendidikannya.

Sekolah Menengah Atas (SMA) merupakan salah satu lembaga pendidikan formal yang dituntut harus mampu mengembangkan seluruh potensi yang dimiliki oleh peserta didik terutama dalam menyiapkan peserta didik untuk dapat berpartisipasi langsung dalam masyarakat. Pengembangan potensi tersebut tidak dapat di pisahkan dari kehidupan sosial baik di sekolah maupun di tengah-tengah masyarakat. Oleh karena itu, guru di wajibkan untuk dapat menguasai kompetensi sosial yang memadai kedepannya. SMA Negeri 7 Kerinci sebagai bagian dari salah satu lembaga pendidikan formal tekait yang juga tentunya harus memiliki kepemimpinan kepala sekolah yang baik guna menunjang peran kepala sekolah sebagai pemimpin yang secara tidak langsung harus mampu memimpin dan memotivasi diri sendiri juga orang lain serta memiliki kemauan dalam upaya mengembangkan dan meningkatkan kompetensi sosial guru.

Kompetensi sosial berkaitan dengan kemampuan pendidik sebagai bagian dari masyarakat untuk berkomunikasi dan bergaul secara efektif dengan siswa, sesama pendidik, tenaga kependidikan, orang tua/wali siswa, dan masyarakat sekitar, yaitu: 1) Berkomunikasi dan bergaul secara efektif. 2) Manajemen hubungan antara sekolah dan masyarakat. 3) Ikut berperan aktif dalam masyarakat. 4) Menjadi agen Perubahan Sosial. [4].

Dari observasi awal yang dilaksanakan di SMA Negeri 7 Kerinci ditemukan bahwa masih terdapat ketidaksepahaman dan bentuk realisasi pembinaan kompetensi sosial guru yang kurang efektif antara kepala sekolah dengan beberapa orang guru, staf pegawai serta masih adanya ketidaksinkronan informasi yang 
disampaikan oleh kepala sekolah dengan informasi yang disampaikan dan dijalankan oleh guru dalam rangka membina kompetensi sosial guru.

\section{METODE}

Kegiatan penelitian ini dilaksanakan dalam kurun waktu Januari hingga Juni 2020. Dalam penelitian ini pengumpulan data yang utama adalah observasi partisipan, wawancara dan studi dokumen serta dokumentasi. Observasi Penelitian ini menggunakan teknik Observasi dimana dalam observasi partisipatif peneliti mengamati apa yang di kerjakan orang, mendengarkan apa yang mereka katakan dan berpartisipasi dalam kegiatan mereka. [5].

Wawancara kualitatif terjadi ketika para peneliti menanyakan kepada seseorang atau lebih partisipan, pertanyaanpertanyaan umum yang open-ended dan mencatat jawaban mereka. Studi dokumen pada penelitian ini terfokus pada dokumendokumen yang ada di SMA Negeri 7 Kerinci sebagai bukti penunjang dalam keakuratan hasil penelitian. Dimana dokumen tersebut meliputi: 1) Data sejarah dan letak geografis SMA Negeri 7 Kerinci. 2) Data Profil SMA Negeri 7 Kerinci, 3) Data tenaga pendidik dan kependidikan SMA Negeri 7 Kerinci, 4) Visi dan Misi SMA Negeri 7 Kerinci, 5) Tugas pokok dan fungsi dari Kepala sekolah, wakil kepala sekolah, staff dan guru serta seluruh warga sekolah SMA Negeri 7 Kerinci, 6) Data peserta didik SMA Negeri 7 Kerinci, dan 7) Data sarana dan prasarana SMA Negeri 7 Kerinci. Sementara dokumentasi digunakan untuk memperoleh data tentang informasi sekolah, profil dan dokumen pendukung lainnya. Dokumentasi ini di kumpulkan untuk mendukung penelitian ini dan kemudian di analisis.

Analisis data dalam penelitian kualitatif dilakukan sejak sebelum memasuki lapangan, selama dilapangan dan setelah selesai di lapangan. Dan dalam penelitian kualitatif data di peroleh dari berbagai sumber, dengan menggunakan data yang bermacam-macam dan dilakukan terus menerus sampai datanya penuh. Untuk menyajikan data agar lebih bermakna dan mulai di pahami maka langkah analisis data yang di gunakan dalam penelitian ini adalah analysis interactif model. [6]

\section{HASIL DAN PEMBAHASAN}

Dalam rangka meningkatkan kompetensi sosial guru maka kepala sekolah perlu membuat program-program penunjang seperti: 1) Piket Simpatik, bentuk pembinaan kompetensi sosial yang berorientasi pada sikap objektif, tidak diskriminatif dan berkomunikasi secara efektif melalui kegiatan, 2) Musyawarah Guru Mata Pelajaran (MGMP), Pembinaan kompetensi sosial yang berorientasi pada sikap objektif, tidak diskriminatif dan berkomunikasi secara efektif, 3) Sinergy Building, bentuk pembinaan kompetensi sosial yang berorientasi pada kemampuan beradaptasi dan berkomunikasi secara efektif. [7].

Berdasarkan hasil wawancara dan observasi terkait implementasi kepemimpinan kepala sekolah dalam membina komunikasi dan bergaul secara efektif, ditemukan bahwa komunikasi dan pergaulan yang terjalin antara kepala sekolah dengan wakil kepala sekolah sudah berjalan secara efektif. Disamping karena menjalankan tugas pokok dan fungsi yang saling berhubungan antara kepala sekolah dengan wakil kepala sekolah disisi lain juga dikarenakan oleh ruang kepala sekolah dan wakil kepala sekolah yang bersebelahan. Sehingga komunikasi yang terjalin setiap harinya akan lebih terasa lebih akrab dan tidak canggung. Sedangkan komunikasi yang terjalin antara kepala sekolah dengan guru dapat dikategorikan belum maksimal. Hal ini 
dikarenakan kepala sekolah yang sering kali jarang memperhatikan aktivitas atau kegiatan guru di sekolah. Kepala sekolah sering kali hanya berkumpul dan berada di ruangannya saja. Sedangkan aktivitas lain seperti mengecek guru saat proses belajar mengajar pun jarang dilakukan. Ditambah dengan jarak antara ruang kepala sekolah dengan ruang majelis guru yang tidak berdekatan.

Kepala sekolah harus dapat mengetahui dasar dari menciptakan komunikasi yang efektif adalah dengan memahami beberapa nilai yang harus dipahami pada saat berkomunikasi dengan guru. Kepala sekolah harus memahami karakter, kepribadian masing-masing guru sehingga kepala sekolah pada saat berkomunikasi dapat lebih efektif dan mudah dimengerti oleh guru sebagai penerima pesan. Jika komunikasi efektif dapat dilakukan oleh kepala sekolah dengan baik maka motivasi kerja guru akan meningkat. [8].

Namun disisi lain terjalin komunikasi yang baik antar seluruh elemen sekolah hal ini dibuktikan dengan aktivitas guru yang selalu rutin berada di gerbang sekolah setiap pagi sesuai dengan jadwal piketnya masing-masing secara bergantian. Artinya setiap hari akan selalu ada guru yang menyambut siswa secara bergantian hal ini di maksud agar siswa memberikan salam kepada guru sebelum masuk ke ruang kelas dan memulai pelajaran.

Berdasarkan hasil wawancara dan observasi terkait implementasi kepemimpinan kepala sekolah dalam memanajemen hubungan antara sekolah dengan masyarakat sudah cukup baik.Hal ini dapat dibuktikan bahwa dengan melibatan beberapa guru dalam kegiatan sosial masyarakat di sekitar sekolah seperti gotong royong ataupun ada berita duka dari masyarakat sekitar.
Hal ini dikarenakan pemahaman bahwa guru bukan saja menghubungkan muridmuridnya dalam kehidupan bermasyarakat, tetapi ia sendiri perlu berpartisipasi secara aktif di dalam masyarakat. Di sekolah ia bertindak sebagai guru dan di masyarakat pun ia bertindak sebagai guru karena sekolah dan masyarakat tidak dapat dipisahkan. [9]

Berdasarkan hasil wawancara dan obsevasi terkait implementasi kepemimpinan kepala sekolah dalam membina guru untuk ikut berperan aktif dalam masyarakat ditemukan bahwa sebagian besar guru lebih berperan aktif dalam kegiatan sosial masyarakat yang ada di lingkungan tempat tinggal masing-masing. Dan mengenai arahan hanya beberapa guru saja yang mendapat arahan langsung dari kepala sekolah untuk dapat berperan aktif dimasyarakat sekitar sekolah seperti wakil kepala bidang hubungan masyarakat dan bidang kesiswaan.

Dalam lingkungannya (masyarakat umum dan sekolah), guru merupakan teladan yang patut dicontoh dalam kehidupan mereka sehari-hari. Hal ini menuntut kemampuan sosial guru dengan masyakat, sebagai upaya mewujudkan proses pembelajaran yang efektif dan akan mempengaruhi hubungan sekolah dengan masyarkat lebih baik lagi. Dalam kemampuan sosial tersebut, meliputi kemampuan guru dalam berkomunikasi, bekerja sama, bergaul simpatik dan mempunyai jiwa yang menyenangkan. [10].

Berdasarkan hasil observasi dan wawancara terkait implementasi kepemimpinan kepala sekolah dalam membina guru menjadi agen perubahan sosial di SMA Negeri 7 Kerinci belum terlaksana secara optimal. Hal ini dikarenakan kepala sekolah hanya melibatkan guru dalam bentuk pelatihan 
yang diadakan oleh dinas pendidikan terkait saja. Sedangkan untuk pelatihan di sekolah kepala sekolah belum pernah menyelenggarakannya. Namun kepala sekolah selalu memberikan arahan serta penjelasan dalam rapat awal dan akhir semester mengenai tugas pokok dan fungsi guru.

Guru sebagai agen perubahan (agent of change) merupakan bagian yang terpenting dalam lingkup pendidikan. Artinya, guru sebagai panglima utama yang bertugas membawa perubahan seseorang yang pada awalnya tidak tahu menjadi tahu dari hasil proses kegiatan belajar dan mengajar serta penerapan nilai-nilai positif, baik secara privat maupun publik yang dilaksanakan secara profesional. [11].

Faktor pendukung dalam membina Kompetensi Sosial Guru di SMA Negeri 7 Kerinci adalah sebagai berikut : 1) Terjalin hubungan yang baik antar kepala sekolah, dan wakil kepala sekolah. Sehingga komunikasi sosial dan pergaulan sosial berjalan cukup efektif. 2) Masyarakat sangat menghargai guru sebagai seseorang yang mampu mendorong pemahaman dan toleransi antara sekolah dan masyarakat sehingga hubungan sosial dan menyampaian informasi bisa terjalin dengan baik.

Sedangkan Faktor Penghambat dalam Kompetensi Sosial Guru di SMA Negeri 7 Kerinci adalah sebagai berikut : 1) Status SMA Negeri 7 Kerinci adalah milik pemerintah yang mengharuskan setiap kebijakan atau peraturan yang dibuat disesuaikan dengan arahan dan aturan dari Dinas Pendidikan setempat. 2) Masih kurang nya apresiasi dan inisiatif baik dari Kepala sekolah maupun guru dalam menimbulkan interaksi sosial antara sekolah dan masyarakat sehingga belum berjalan secara maksimal. 3) Posisi ruang kepala sekolah, wakil kepala sekolah yang tidak berdampingan langsung mengakibatkan implementasi kepala sekolah dalam membina kompetensi sosial masih rendah, sehingga sering kali hanya wakil kepala sekolah saja yang terlibat.

Oleh karena itu, kepala sekolah seharusnya perlu menerapkan komunikasi dengan pendidik,tenaga kependidikan, orang tua atau wali peserta didik dan masyarakat. Untuk meningkatkan dan mengembangkan kompetensi sosial yang dimiliki oleh guru, sekolah juga perlu menerapkan beberapa upaya yang dilakukan, diantaranya adalah Pertemuan Wali Murid sebagai Upaya Meningkatkan Kemampuan Berkomunikasi Guru dengan Orang Tua Siswa, Rapat Guru sebagai Upaya Meningkatkan Kemampuan Berkomunikasi dengan Teman Sejawat, Pembinaan dari Kepala Sekolah Melalui Kegiatan Supervisi. [12]

Secara umum, implementasi kepemimpinan kepala sekolah dalam membina kompetensi sosial guru di SMA Negeri 7 Kerinci sudah cukup baik. Akan tetapi Hasil dari Penelitian ini menunjukkan bahwa ada beberapa hal yang menjadi permasalahan di SMA Negeri 7 Kerinci. Salah satunya yaitu minim nya upaya sekolah dalam melaksanakan kegiatan atau bentuk pelatihan dalam rangka meningkatkan kompetensi sosial guru. Sedangkan dari segi komunikasi juga terdapat beberapa poin yang belum maksimal yaitu adanya aktivitas guru yang tebagi menjadi beberapa kelompok yang henya berkumpul di ruangan tetentu saja.Sehingga jarang terjadi interaksi dengan kelompok lainnya serta agenda pertemuan dengan wali murid hanya dilaksanakan pada saat pembagian hasil belajar siswa serta rapat komite saja.

\section{SIMPULAN}

Berdasarkan analisis serta pembahasan hasil data wawancara dan observasi yang 
telah peneliti laksanakan di SMA Negeri 7 Kerinci bersama dengan 7 orang partisipan terkait implementasi kepemimpinan kepala sekolah dalam membinakompetensi sosial guru maka peneliti dapat menarik kesimpulan sebagai berikut :

1. Implementasi Kepemimpinan Kepala Sekolah dalam membina kompetensi sosial Guru di SMA Negeri 7 Kerinci sudah berjalan cukup baik. Hal ini dibuktikan dengan adanya penerapan pertemuan dengan wali murid dan piket simpatik yang melibatkan seluruh elemen sekolah untuk berada di gerbang sekolah setiap paginya secara bergantian sesuai dengan jadwal piketnya masing-masing. Kemudian manajemen hubungan antara sekolah dan masyarakatserta ikut berperan aktif di masyarakat sudah cukup baik dengan adanya penerapan synergy building yaitu bentuk kegiatan interaksi sosial antara pihak sekolah dan guru dengan masyarakat sekitar. Selanjutnya menjadi agen perubahan sosial belum terlaksana secara optimal karena masih sangat minim bentuk pelatihan bagi guru dalam meningkatkan kompetensi sosial guru namun sudah adanya bentuk penerapan pembinaan MGMP dimana kepala sekolah secara rutin melaksanakan rapat setiap awal tahun ajaran baru dan akhir tahun ajaran dengan membahas den menekankan pada tugas pokok seorang pendidik.

2. Faktor pendukung dalam membina kompetensi sosial guru di SMA Negeri 7 Kerinci adalah sebagai berikut : 1) Terjalin hubungan yang baik antar kepala sekolah, dan wakil kepala sekolah. Sehingga komunikasi sosial dan pergaulan sosial berjalan cukup efektif. 2) Masyarakat sangat menghargai guru sebagai seseorang yang mampu mendorong pemahaman dan toleransi antara sekolah dan masyarakat sehingga hubungan sosial dan menyampaian informasi bisa terjalin dengan baik

3. Faktor penghambat dalam membina kompetensi sosial guru di SMA Negeri 7 Kerinci adalah sebagai berikut : : 1) Status SMA Negeri 7 Kerinci adalah milik pemerintah yang mengharuskan setiap kebijakan atau peraturan yang dibuat disesuaikan dengan arahan dan aturan dari Dinas Pendidikan setempat. 2) Masih kurangnya apresiasi dan inisiatif baik dari kepala sekolah maupun guru dalam menimbulkan interaksi sosial antara sekolah dan masyarakat sehingga belum berjalan secara maksimal. 3) Posisi ruang kepala sekolah, wakil kepala sekolah yang tidak berdampingan langsung mengakibatkan implementasi kepala sekolah dalam membina kompetensi sosial masih rendah, sehingga sering kali hanya wakil kepala sekolah saja yang terlibat.

Berdasarkan beberapa kesimpulan yang terpapar diatas, beberapa poin saran yang peneliti sampaikan adalah sebagai berikut :

1. Kepada kepala sekolah sebagai penanggung jawab agar dapat lebih mengoptimalkan dalammenjalin komunikasi yang baik dengan wakil kepala sekolah, guru dan seluruh warga sekolah. Tetapi juga berupaya untuk membina kompetensi sosial guru di SMA Negeri 7 Kerinci melalui upaya pelatihan dan pembinaan bagi guru. Agar dapat meningkatkan kualitas kompetensi sosial yang dimiliki oleh guru di SMA Negeri 7 Kerinci.

2. Kepada wakil kepala sekolah sebagai jajaran dalam stakeholder sekolah. Agar lebih maksimal dalam membina kompetensi sosial guru. Dan lebih aktif dalam mengajak guru untuk lebih bersosialis dan berperan aktif di tengah masyarakat.

3. Kepada guru sebagai bagian dari satuan pendidikan agar lebih aktif dan 
meningkatkan kesadaran akan pentingnya peran guru sebagai agen perubahan sosial. Sehingga secara tidak langsung dapat meningkatkan pengalaman dalam segi Kompetensi sosial guru.

4. Pihak sekolah dan kepala sekolah agar lebih mensosialisasikan secara optimal tentang pentingnya Kompetensi sosial bagi guru agar dapat berperan aktif dan menjadi agen perubahan sosial di tengah masyarakat.

\section{DAFTAR PUSTAKA}

[1] Peraturan Menteri Pendidikan Nasiona Nomor 162 Tahun 2003 tentang Pedoman Penugasan Guru sebagai Kepala Sekolah.

[2] Susanto \& Mulyadi, "Peran Kepala Sekolah dalam Pengembangan Potensi Guru di Sekolah Menengah Pertama Negeri." Jurnal Akintabilitas Manajemen Pendidikan Volume 4 Nomor 2 September 2016 hal. 151163, 2016.

[3] Departemen Pendidikan Nasional.

Standar Kompetensi Kepala Sekolah $T K, S D, S M P, S M A / S M K$ dan SLB. Jakarta: Cipta Karya, 2006.

[4] J. Suprahatiningrum. Pedoman Kinerja Kualifikasi dan Kompetensi Guru. Yogyakarta: Ar-Ruzz Media, 2013.

[5] Sugiyono. Metode Penelitian

Kuantitatif, Kualitatif dan $R \& D$. Bandung: Alfabeta, 2012.

[6] Sugiyono. Metode Penelitian

Pendidikan (Pendekatan Kuantitatif, Kualitatif dan $R \& D)$. Bandung: Alfabeta, 2015.

[7] B. Wahrudin. Pola Pembinaan Kompetensi Kepribadian dan Kompetensi Sosial Guru di SMA Muhammadiyah 1 Ponorogo. Jurnal Pendidikan Islam Volume 11 Nomor 2 Tahun 2017 hal. 137-156, 2017.

[8] I.D. Lestari. Implementasi Komunikasi Efektif Kepala Sekolah dalam Meningkatkan Motivasi Kerja Guru di
SDN Mekarjaya 30 Depok. Susunan Artikel Pendidikan Volume 3 Nomor 3 April 2019 hal. 195-201, 2019.

[9] A. Amin. Hubungan Kompetensi

Sosial Guru dengan Interaksi Edukatif dalam Perspektif Peserta Didik. AL-BIDAYAH: Jurnal Pendidikan Dasar Islam Volume 11 Nomor 01 Juni 2019 hal. 77-106, 2019.

[10] D. Rahadian. Peran dan Kedudukan Guru dalam Masyarakat. Jurnal Pendidikan Teknologi dan Informasi Volume 1 Nomor 1 Mei 2018 hal. 2637, 2018.

[11] Andrian. Perspektif Guru sebagai Agen Pembaharu (Agent of Change) dalam Meningkatkan Kualitas Pendidikan Kewarganegaraan. UCEJ: Untirta Civic Education Journal Volume 3 Nomor 1 April 2018 hal. 79-100, 2018.

[12] A. Chumaida. Upaya Sekolah dalam Meningkatkan Kompetensi Guru PAI yang Belum Tersertifikasi di MA AlHikmah Langkapan Srengat, Blitar. BRILLIANT: Jurnal Riset dan Konseptual Volume 2 Nomor 4 November 2017 hal. 470-481, 2017. 